Canadian University Music Review

Canadian University Music Review

Revue de musique des universités canadiennes

\title{
On Popular Music: Philip Tagg, William Straw / À propos de musique populaire : Philip Tagg, William Straw
}

\section{Julie Pedneault}

Volume 23, numéro 1-2, 2003

URI : https://id.erudit.org/iderudit/1014516ar

DOI : https://doi.org/10.7202/1014516ar

Aller au sommaire du numéro

\section{Éditeur(s)}

Canadian University Music Society / Société de musique des universités canadiennes

ISSN

0710-0353 (imprimé)

2291-2436 (numérique)

Découvrir la revue

\section{Citer ce document}

Pedneault, J. (2003). On Popular Music: Philip Tagg, William Straw / À propos de musique populaire : Philip Tagg, William Straw. Canadian University Music Review / Revue de musique des universités canadiennes, 23(1-2), 1-9.

https://doi.org/10.7202/1014516ar
Résumé de l'article

$\mathrm{Au}$ cours de la dernière décennie, l'étude de la musique populaire s'est graduellement imposée comme l'une des branches de la musicologie avec laquelle il faut désormais compter. Montréal est-elle sur la voie de devenir un des centres d'une telle institutionnalisation? William Straw et Philip Tagg, respectivement directeur du Programme d'études supérieures en communications de l'Université McGill et professeur titulaire à la Faculté de musique de l'Université de Montréal, discutent du présent et de l'avenir de cette discipline. Ils s'expriment également au sujet de la place qu'elle peut occuper dans le cursus universitaire et de ses orientations les plus actives et prometteuses.
All Rights Reserved ( C Canadian University Music Society / Société de musique des universités canadiennes, 2004
Ce document est protégé par la loi sur le droit d'auteur. L’utilisation des services d'Érudit (y compris la reproduction) est assujettie à sa politique d'utilisation que vous pouvez consulter en ligne.

https://apropos.erudit.org/fr/usagers/politique-dutilisation/ 


\title{
COLLOQUY/DÉBAT ${ }^{1}$ : ON POPULAR MUSIC / À PROPOS DE MUSIQUE POPULAIRE : PHILIP TAGG ${ }^{2}$, WILLIAM STRAW ${ }^{3}$
}

\author{
Julie Pedneault (interviewer/intervieweuse)
}

Julie Pedneault : Avec la venue de M. Tagg, l'Université de Montréal a posé un geste important pour reconnaitre et soutenir le champ de recherche sur la musique populaire. Comment décririez-vous la situation présente et les progrès de votre discipline académique au cours des dernières années?

William Straw : Dans le département de communications, nous recevons de plus en plus [de demandes d'admission]; de plus en plus d'étudiants [qui s'intéressent à la musique populaire viennent] faire une maîtrise ou un doctorat, so it is becoming more and more important. At McGill, until very recently, there was not much popular music in the Faculty of music, but now with Philip here, Bob White in anthropology at Université de Montréal, and Chip Whitesell at McGill, we're thinking that something could happen. ${ }^{4}$ Maybe we could start thinking about a joint project, or even look at possibilities of doctorat conjoint, or other interdisciplinary projects in popular music.

Philip Tagg : Yes, we hope to be able to start something like that, although maybe not on too formal a basis initially. But with Serge Lacasse in Québec as well, and Line Grenier, director of the Département de communication at Université de Montréal - and I just had a call from l'UQÀM as well [Université du Québec à Montréal] - there is a possibility for us to pool our resources. We are intending to get together and to discuss possibilities. Unfortunately, there are too few of us. We are not fantastic, but we are fantastically few! But Montréal is one the best places in the world for us, that has already attracted people who specialize in popular music. I would say that there are more popular

1 La conversation s'étant déroulée en français et en anglais, nous avons décidé de préserver l'alternance des langues dans la transcription - NDLR. Since French and English were alternating during the conversation, we have decided to leave the discussion as it occurred-ED.

2 Philip Tagg est professeur titulaire à la Faculté de musique de l'Université de Montréal. Philip Tagg is Full Professor at the Faculté de musique, Université de Montréal.

3 William Straw occupe les postes de directeur suppléant du Département d'histoire de l'art et d'études en communications et de directeur du programme d'études supérieures en communications à l'Université McGill. William Straw is both Acting Chair of the Department of Art History and Communications Studies and Director of the Graduate Program in Communications at McGill University.

4 Ajoutons que depuis cette entrevue, la Faculté de musique de McGill a embauché David Brackett, musicologue spécialisé en musique populaire - NDLR. Since this interview, David Brackett, a popular music musicologist, has been hired at the Faculty of Music, McGill University-ED. 
music scholars in Québec per square kilometre that there are in many parts of the world!

\section{J. P. : Même en comparant avec les États-Unis?}

P. T. : In the United States, I would say that there are a lot of undergraduate courses where Rock History or Music Business may be offered. But there is not a lot in the way of graduate studies. The research tends to be very general, more historical, I would say less interdisciplinary than the type of research that we hope to be able to do here.

W. S. : For nine years, from 1984 to 1993, I taught at Carleton University. There we had Jody Berland, John Shepherd, Paul Théberge, myself; Jocelyne Guilbault was in University of Ottawa. Nous étions toujours sur le point de lancer quelque chose, comme un programme d'études supérieures - et puis plusieurs personnes sont parties, and I think we sort of missed the boat at the moment. There is still very interesting stuff at Carleton, but I think now there is a lot of energy in Montréal. For the past years, all of us have been working in solitude. It is just a person here and there, but now we have more resources and if we get together we can make progress.

P. T. : We'll have to see over the years.

J. P. : En ce moment, quelles branches de la discipline considérez-vous comme les plus actives, les plus prometteuses?

P. T. : There have been some encouraging developments in the last five or six years in popular music studies: more musicians and musicologists are coming to it. In the late eighties and the beginning of the nineties, there was an understandable and historically explainable déséquilibre in favor of metamusical studies-society and music, communications, ethnographical studies and so on, but there was very little coming from music and musicology, about the sounds of music. From my own experience, the popular music studies were quite marginalized. There are historical reasons for that, obviously. Communication studies will foreground the sociologists who are interested in studying youth culture (this is a very early development in cultural studies schools like the Birmingham school in the UK, in the sixties and the seventies). In music and musicology, faculties and departments of music have worldwide been very slow to encourage the research and systematic teaching of anything to do with popular music.

W. S. : In the last five years or so, we started in communications to build courses up on music scenes, music subculture, music and cities. That has been very interesting, and I would say that is probably the dominant trend at the moment.

P. T. : It is completely explainable in historical terms. It is what the pop music papers talk about: music in terms of B minor seven, of what Shania Twain was wearing, of people dying at a heavy metal concert. It will be more about the scene or the presentation than about what the sounds actually are in musical terms and how they come to mean in specific situations. This, I am very 
encouraged to say, is changing and they are more people coming to the field of popular music from the music faculties, people who don't wear narrow blinders and who are not just "Musos". They are quite widely educated, they can contextualize the sounds of music and their analysis of music. I see that as one of the greatest improvements in popular music studies. And I think that popular music studies, if it continues in this way, will have a lot to offer to classical music studies.

\section{J. P. : Par exemple?}

P. T. : I think a lot of historical studies of, say, Viennese classicism, miss the point that Vienna, in late eighteenth-century, was sociologically and demographically very similar to Chicago in the 1940 s and 1950 s, that is to say a melting-pot of hundreds of different cultures. It was also, as Chicago and New York, the centre of a great empire, and that empire meant a lot to the bourgeoisie and merchant class who needed to have some type of entertainment with which they could identify. Without that historical background, Viennese classicism-Haydn, Mozart, Beethoven, Schubert-would probably never have existed, or at least would not have had the same opportunities. There are a lot of questions to ask about what is a too complicated issue to debate in an interview, but it is not fortuitous that the sonatas and all the instrumental music that we regard as classical today (and which did not actually get called classical before the 1930s), were developed for specific needs at a specific time in history. I think there are ways to understand what classical music means and signifies that need to be addressed; and popular music studies, with its interdisciplinary character (which must include the study of musical sounds), can help. Pop music scholars could really help open up that whole field of research if they went into classical music.

J. P. : Do you think that at some point popular music could become a complete part of the academy, both in performance and in scholarship?

P. T. : In performance, less so but in scholarship, yes, it could do. First of all, in a Faculty like this one, there are a lot of younger members of staff, experts of classical music, who were brought up with Credence Clearwater Revival, who were raised on pop music, rock and roll and so on, and who don't identify with classical music as an elite culture. Their attitude towards pop music is quite different from one generation ago. That is one way in which it can start to be incorporated in the academy. And obviously, the research into popular music, by which I would include everything from video-game music and film music to quite avant-garde rockcore [...], will become more and more part of academic interests. As television and the audiovisual media grow up, people want explanations as to what is being communicated, and it is our job to try finding ways of answering those questions. That has to be part of academic research, it is an imperative. When it comes to performance, on the other hand, since music-making reacts so immediately to the social configuration in which it finds itself (it comes out of it, and feeds back into it), universities are like oil tankers: it takes five kilometres and two hours to stop them, and they go very 
slowly. It is very difficult to institutionalize aspects of performance, as well as certain aspects of musical creativity, because by the time you have implemented one change, that change will not necessarily be up to date, or any good any longer. You can just imagine being in 1963 or 1964, and having a guitarist making distortion: that is bad in 1963! But then it becomes a means of expression in or around 1964, when we saw somebody play like Hendrix. So the student from the previous year complains about his having marks deducted because of the distortion, when now marks are given for it! So how do you regulate that in a university system? Another example, everybody is supposed to be... say, ballad-singing like Elton John-and then Kurt Cobain comes along. (Well, that is not singing, you can't sing like that!) But then that becomes canonic after a year or so. And they institutionalize the Kurt Cobain vocal style... It is not in the nature of a university to be able to adapt so quickly to immediate needs. Will pop music become a complete part of the academy, then? Yes in terms of research, no in terms of performance.

W. S. : For so long, media studies, which is my area, looked at television, radio and films, but not music. And then people began to ask "why not music?" The students wanted (and still want) to write about the music and the celebrities in contemporary culture. There were music faculties-but we realised they were not doing it. Today, hundreds of people are going into communication programs and studying pop music. Now, I probably met Philip twenty years ago at one of the original meetings of IASPM [International Association for Studies in Popular Music]. At that time, there were a lot of musicologists and people like me, and there was a good dialogue. Then I think in the next twenty years there was sort of a separation; people did not talk to each other so much; popular music studies, cultural studies and media studies developed kind of autonomously. Meanwhile there were changes within music departments themselves. Now we can sort of come back together. There are questions like technology, not just technologies of dissemination but of production and the Internet. These are not just musical questions, but the music faculties have to look at them. And there are communication questions, but we do need to think about music too. I really think the idea of sound is central-in a sociological sense, in a formal sense, in an artistic sense. That must become or remain a point of convergence.

J. P. : Le cheminement d'un étudiant qui souhaite se spécialiser en musique populaire, en musique autant qu'en communications, passe donc par la multidisciplinarité?

P. T. : Any decent study of popular music, whether oriented on musicology or on communications, will have to be at least to some extent interdisciplinary. That is why a doctorat conjoint is a very good idea; we would really like to work on that kind of project. If the student is a musician and is interested in musical analysis, he should go to a music department or faculty where somebody like Serge Lacasse can help him or her in that, and can point the student in the directions of literature and experts in other areas. We have to work in 
these ways. But we should all be reasonably educated, have a general knowledge of the whole area, on both sides of the collaboration. We have to do something to force an opening between these two disciplines.

J. P. : Dans quelle mesure croyez-vous que la musique populaire devrait figurer dans le programme régulier d'un étudiant en musique classique?

P. T. : Pour la faculté de musique, mon opinion est que tout le monde devrait être obligé de suivre au moins un cours de base sur les esthétiques et les styles de la musique populaire, autant anglo-saxonne que francophone et internationale, afin de revoir l'histoire conventionnelle de la musique européenne et nord-américaine. Il faut vraiment que ça soit fait et que tout le monde suive le cours pour comprendre qui étaient au fond Bach et Schubert, non seulement [...] Hendrix et Cobain. Mais ce sont des projets à long terme, because we don't have enough people to deliver these things. Here in Université de Montréal, it is an option at the moment, but quite a popular one. We will have to take on teaching assistants anyhow, which is very good because the more teaching assistants we take on, the more people will be qualified to deliver that teaching, and the more courses we can offer. Therefore, we can make some courses obligatory for all students.

W. S. : At McGill, like in many universities, you have this strange thing where the faculty of arts will teach you literature, painting, poetry, drama, television, but not music. Historically, music has had its own faculty (there are excellent reasons for that of course), so students can learn about all the arts except music. With time, faculties of music began to realize that they could do music for arts students and get hundreds of registrations. They began to do it and found that it could work, but there is still this strange clivage between the two faculties. And if we, in the faculty of arts, say "Why don't we do a course on the history of popular music?", the Faculty of music says "no, no, you can't do a course on music." We need to find ways to work together.

P. T. : It causes such a problem; it is so absurd when you think of the contradictions there. Here you have these mediums like video games, computer games, which have constant music or soundtracks, which use modern techniques of digital imaging. How come all these other aspects of such a production, which is hugely popular (six times more popular than renting a video or a DVD in the USA - quite extraordinary!), [are left aside?] More people in the USA recognize the Super Mario Brothers' main theme than recognize the Mickey Mouse theme. Television, films, video or computer games-these areas are where everything is in the package-are where most music is now heard-not just as music. Of course, people listen to radio in the car, in the background at home, or in the shopping mall, so there is still a lot of music being heard as music. But a large proportion of music that you hear in your everyday life is actually accompanying images, or has images which accompany it. But music is institutionally way outside! This is utterly crazy. These things should be combined, as they are in reality; you should study them like as a package. 
J. P. : Envisagez-vous la possibilité qu'un jour un programme complet puisse être offert en musique populaire, de la même manière qu'on a aujourd'hui des écoles universitaires de jazz?

W. S. : I only teach one course in popular music every two years, because most of the students don't want just to learn only about popular music and I can't justify having five courses in pop music. I also have to teach courses on television, film and so on. What do I bring to popular music studies? I am a specialist in the music industry, in the sociological approaches to popular music [and I study] a little bit of history of media of popular music. But there are a million things that I can't do that Philip can do, and he can actually do it in a way that I can understand, because the way he talks about film music corresponds to what I find interesting about film music. It is not only "did you know this was a D minor chord?" I think Philip is a rare kind of popular music scholar, who can translate the formal questions into terms that correspond to what I think is interesting. You could analyse a poem in linguistic terms, but would that have anything to do with what is interesting about it?

P. T. : He has hit the nail on the head. It is like the architect who goes to study buildings and talks about the bricks.

W. S. : Je ne suis pas intéressé à collaborer avec n'importe qui en musique, mais il y en a comme lui, comme beaucoup d'ethnomusicologues aujourd'hui, comme Serge Lacasse aussi, qui ont une sensibilité qui fait que je trouve intéressant de parler avec eux. Lui et Serge sont deux des rares qui savent en parler sans aliéner les gens qui ne comprennent [pas] ce que telle note fait ici, ou quelle est telle construction d'accord.

P. T. : One big problem with music studies in general, which makes it difficult to incorporate them in an interdisciplinary context, is this: most of the terms describing musical structure have to do with its construction, with how as a musician or a composer you put the sounds together. Every description, every word that describe a chord, for example, does not tell you how the chord feels or how you perceive the chord, but how you construct it. Whereas when you go to visual arts, if you see a painted dog in a picture, you don't say: "that is a kind of fractal, inverted cyan 95," etc.

W. S. : Or if you eat a crème caramel...

P. T. : The training of a musician, of a music theorist, relies so much on a vocabulary that is not conducive to understanding signification. It is conducive to the construction of music, but not to the vast majority of people who mostly consume it for dancing, video games, movies, etc. People like that want to know what does what? How does it work? Why do I feel this way? As technology changes, so will the way in which we describe musical structures. So now, with sampling, you don't need to say it is a D minor seven flat five.

W. S. : You could say it is James Brown's "Funky Drummer."

P. T. : This is a problem that constructors of music and composition softwares have: how to denote certain particular samples, how do you name [that]? 
J. P : Croyez-vous que la discussion musicale structurelle demeure tout de même pertinente et significative?

P. T. : The simple answer is yes! In my graduate seminar, we don't only deal with the aspects of music that you could put in notation, we also deal with the ones that are not in notation. Yesterday, we spent half an hour speaking about XTC, the vocal production of one word. In this instance, the singer gets to a note which is in about mid-register, and he starts with an angry and quite gruffly voice. But then, towards the end of the note, he swallows, he gulps it, and goes into falsetto. You have to get everybody in the class to do it, or at least to try to do it, so they can feel what emotion, what gesture, what posture are necessary to accompany such a vocal production. So the analysis has to include these levels of cognition as well-it has to. Because these are intimate things that can be easily recorded in the microphone, but that are not visible on the paper. So that is one important aspect: timbre, vocal production and vocal persona - there are all sorts of standard types of both men and women present in vocal form. The other aspect is to look at what instruments do, not just in terms of harmony and pitch, but also in what timbre is being used. We talk a lot about rhythm and recurrence, and the way the recurrence is constructed. You can maybe start with the diminished sevenths, but it is always related to how it comes across, so people will be saying, in the analysis classes: "this chord reminds me of the same chord that you would get in a silent film for horror." So let's call that a silent-film-horror chord. And you can start making links between the constructional and the perceptual aspects of music. If we go in that way in musical analysis, I am sure we will be of far more use to people in communications and others outside conventional music studies. It is also possible to run such classes in communication studies.

W. S. : You could teach in a way that builds up complicated method by adding on level to level. The difference is that most of my students are not interested in music as their number one specialization. So, you use music partly because the students are interested in it, but also partly because music is a good example to get them to think about what is the relationship between form and pleasure and industry and society, etc.

P. T. : And any music study should cover that, any analysis we do in the classroom. Why at this particular time with this audience? Why did they produce sounds of this nature? Does it mean the same to us as it did then? The formalist analysis done in most conventional music departments, [for example] Schenkerian techniques-I am not going to get rid of Schenker, especially for standard classical harmony - but to insist that this is the main way, or the most important way of analysing music in which other premises of expression are equally if not more important, seems to me totally wrong. And this is the problem that so many people, experts in Schenkerian analysis, or in Reti's method, face. 
W. S. : I have sat there in conference-twenty minute conference of a Schenkerian analysis of a Prince song. It does not capture anything of what is interesting about that song, about what makes it meaningful.

P. T. : The best thing I think it can do is actually help the person in question to understand certain aspects of its tonal construction, on the large scale; but that's all. In my view, it shows you forms of recapitulation, that could allow you, if you've done your basic semiotic work, to understand [how the music signifies]—but that is not how it is used; it is an end in itself.

J. P. : Est-ce donc un problème d'enseigner l'analyse de la musique populaire en ce moment, puisqu'il y a peu de vocabulaire ou d'outils de base communs, unifiés?

P. T. : It is both an advantage and a disadvantage. I am sorry to be so political, it is a politician's answer there! It is an advantage because it is quite exciting, it makes people think that what they have to say about the music they hear is important, because we have not got a vocabulary really established at all. And on the other hand it is a mess!

W. S. : It is a mess, but in the study of literature, or the study of films, there are a thousand different methods, and everyone has to create his own method for the study of film. Why does music think "we will come up with the unique method?" Nobody else in the humanities thinks that they will one day if they just work hard, develop a grand method that will include everything; most people recognize it will always be pluralistic.

P. T. : That is a very good point.

J. P. : Et quels sont vos projets pour les prochains mois?

P. T. : Il y a des idées, mais toujours des idées-je viens seulement d'arriver à Montréal. Mais il y a un projet que j'aimerais faire avec des collègues à la faculté de musique, mais aussi avec des collègues comme Line Grenier et Serge Lacasse : discuter ou examiner quelques-uns des personnages les plus fréquents dans la musique populaire récente, c'est-à-dire " the little girlie », " the misunderstood young man ", et d'autres personnages qui reviennent tout le temps. Il faudrait en faire une analyse en sciences naturelles (spectogrammes, etc.) et aussi étudier leur mode de production du son, [mais] surtout avoir des données de base empiriques sur la réception, pour avoir à la fin du compte une idée pourquoi, à cette étape de notre culture, la voix " petite fille " (par exemple) est tellement populaire. Il y a évidemment des liens avec les images des photos-modèles. Je pense que c'est un projet qui est [plutôt] interdisciplinaire, qui pousse à la fois les frontières de l'analyse musicale en systématisant [ne serait-ce que] la description des structures vocales, mais sur une base de perception. L'analyse de la science naturelle et de la production, ça viendra après.

W. S. : Je crois que ça va débuter sur une base informelle; on va se voir et discuter. Un nouveau programme complet impliquerait [présentement] beaucoup d'administration. Mais je sais que ça va arriver un jour. Un étudiant en 
Californie dira : "à Montréal, il y a Philip Tagg, Will Straw, Line Grenier, pourquoi ne pourrais-je pas travailler avec tous les trois? " Et c'est lorsque ces questions-là seront soulevées que les choses commenceront à vraiment bouger. On pourrait déjà le faire de façon informelle.

P. T. : Si on pouvait trouver des moyens mi-officiels pour gérer cette demande... car la demande existe! J'ai un étudiant norvégien qui va arriver vers la fin de mars, qui étudie le rôle du rock dans la chute de l'Union soviétique. Il devra étudier un peu les moyens musicaux qui ont contribué à cette chute! mais devra aussi consulter Will et d'autres professionnels de différents domaines. On parle déjà des possibilités futures de collaboration à plus grande échelle... I think some kind of graduate-study-cooperation-deal would be the best to start with.

J. P. : Merci beaucoup à tous les deux!

\section{Abstract}

In the course of the last decade, the study of popular music has gradually taken its place as one of the most important branches of musicology. Is Montreal on its way to becoming one of the centres of this institutionalization? William Straw (Director of the Graduate Programme in Communication Studies at McGill) and Philip Tagg (senior professor at the University of Montreal) discuss the current state and future of this discipline. They speak both about the field, its place in the university curriculum, and its most active and promising orientations.

\section{Résumé}

Au cours de la dernière décennie, l'étude de la musique populaire s'est graduellement imposée comme l'une des branches de la musicologie avec laquelle il faut désormais compter. Montréal est-elle sur la voie de devenir un des centres d'une telle institutionnalisation? William Straw et Philip Tagg, respectivement directeur du Programme d'études supérieures en communications de l'Université McGill et professeur titulaire à la Faculté de musique de l'Université de Montréal, discutent du présent et de l'avenir de cette discipline. Ils s'expriment également au sujet de la place qu'elle peut occuper dans le cursus universitaire et de ses orientations les plus actives et prometteuses. 